\title{
FEED POTENTIAL OF AGRICULTURE WASTE FOR BEEF CATTLE DEVELOPMENT IN KUNINGAN REGENCY, WEST JAVA
}

\author{
F. T. Farda ${ }^{1}$, E. B. Laconi ${ }^{1,3}$ and S. Mulatsih ${ }^{2}$ \\ ${ }^{1}$ Faculty of Animal Science, Bogor Agricultural University, \\ Jl. Agatis, Darmaga Campus, Bogor 16680 - Indonesia \\ ${ }^{2}$ Faculty of Economy and Management Science, Bogor Agricultural University, \\ Jl. Lingkar Kampus, Gd. Rektorat lt. 3, Darmaga Campus, Bogor 16680 - Indonesia \\ ${ }^{3}$ Corresponding E-mail: elaconi@yahoo.com
}

Received March 09, 2015; Accepted July 28, 2015

\begin{abstract}
ABSTRAK
Tujuan penelitian adalah mengidentifikasi dan menganalisis potensi limbah pertanian yang digunakan sebagai pakan, mengkaji karakteristik peternak sapi pedaging dan mengestimasi kemampuan penambahan populasi sapi pedaging di Kabupaten Kuningan Jawa Barat. Penelitian ini menggunakan data primer dan data sekunder. Data primer diambil dari wawancara dan analisa laboratorium. Wawancara dilakukan terhadap 30 peternak sapi pedaging responden. Responden dipilih secara purposive sampling di tiga kecamatan terpilih berdasarkan data populasi sapi pedaging terbanyak berdasarkan data dinas peternakan Kabupaten Kuningan. Sampel limbah pertanian yang dianalisa untuk uji komposisi nutrien adalah jenis limbah pertanian yang paling banyak digunakan sebagai pakan sapi pedaging. Pengambilan sampel dilakukan secara acak sebanyak tiga kali ulangan. Data sekunder diperoleh dari dinas peternakan, dinas tanaman pangan dan badan pusat statistik (BPS). Hasil penelitian menunjukkan jenis limbah pertanian yang digunakan di Kabupaten Kuningan dari produksi tertinggi sampai terendah adalah jerami padi, jerami ubi jalar, dan jerami kacang tanah dengan sistem pemeliharaan ternak secara tradisional. Kecamatan yang dapat meningkatkan populasi ternak sapi pedaging dari jumlah tertinggi sampai terendah adalah Luragung, Cibingbin, Ciwaru, Subang, Maleber, Cibeureum, Cilebak, Karangkancana dan Cimahi. Disimpulkan, produksi limbah pertanian tertinggi adalah jerami padi dan kecamatan yang memiliki potensi tertinggi untuk pengembangan sapi pedaging di Kabupaten Kuningan adalah Kecamatan Luragung.

Kata kunci: Limbah pertanian, Kabupaten Kuningan, sapi pedaging
\end{abstract}

\begin{abstract}
The aims of research were to identify and analyze potential agricultural waste used as feed, examines the characteristics of beef cattle ranchers and estimate the ability of the addition of beef cattle population in Kuningan Regency. The primary data were taken from interviews with 30 respondents beef cattle farmers selected by purposive sampling in three districts based on the largest beef cattle population as a recommendation by local government of Kuningan Regency Agricultural. Waste samples taken randomly three times to analyze of nutrient composition by proksimat analyze was the type of the most widely used for feed. Secondary data was obtained from Kuningan Regency Veterinary Office, Department of Food Crops and the Central Statistics Agency. The results showed that the type of agricultural waste used in Kuningan Regency from highest to lowest production is rice straw, hay sweet potatoes, peanuts and hay with traditional animal husbandry systems. Districts that can improve beef cattle population from the highest to lowest number was Luragung, Cibingbin, Ciwaru, Subang, Maleber, Cibeureum, Cilebak, Karangkancana and Cimahi. In conclusion, the highest agricultural waste
\end{abstract}


production was rice straw and the highest potential for the development of beef cattle in the Kuningan Regency was Luragung District.

Keywords: agricultural waste, Kuningan Regency, beef cattle

\section{INTRODUCTION}

The development of ruminants production must be accompanied by an increased of the forage provision and quality. Forage for beef cattle reached $40-70 \%$ of feeding. Provision of forage is increasingly difficult due to land limitation for forage fodder cultivation. The land availablity has a higher priority as an able land for human food than for forage crops as a ruminant feed. Provision of forage for ruminant is difficult due to land limitation for forage cultivation in order to an alternative forage is needed (Suprapto, 2013). On the small scale farm, the cattle fed uncertainty forage types depend on fluctuations of feed availability which depend on the season (Imran, 2012). Alternative forage can be obtained from agriculture wastes with huge amount in Indonesia.

The constraint of agricultural wastes usage as beef cattle feed have nutrient deficiencies are the poor quality and the lack information of the agricultural waste potency. Information on types of agricultural waste, agricultural waste, nutrient content and production quantities are considered less. Missing information will cause difficulty in the utilization of agricultural waste as feed.

West Java Province is one of the provinces having potential of livestock and local feed. The one of potential districts in West Java is Kuningan Regency. BPS of Kuningan Regency (2014) showed that number of beef cattle population on 2013 had the highest number compared to dairy cattle, those were 22,957 $\mathrm{AU}$ and 4,529 $\mathrm{AU}$, respectively. However, the use of local feed is still hampered by a lack of information about the potential of these materials and also the characteristics of farmers who carry out farming activities. The objectives of this study were to assess the characteristics of beef cattle farmers in Kuningan Regency-West Java, to analysis the potential of agriculture wastes used as feed and to estimate the ability of addition number of ruminant population, especially beef cattle in Kuningan Regency, West Java.

\section{MATERIALS AND METHODS}

The experiment was conducted in Kuningan
Regency of West Java from August to November 2014. Analysis of the nutrient content of feed was conducted in the Laboratory of Animal Feed Science and Technology, Department of Nutrition and Food Technology, Faculty of Animal Science, Bogor Agricultural University.

This study used two types of data, those were primary and secondary data. Primary data was obtained from interviews with respondents and data from laboratory analysis. Interviews were conducted with 30 farmers respondents that consisted of 10 farmers in each district (Sugiyono, 2011). Criteria for selection of respondents were the beef cattle farmers rearing cattle at least three heads and who use agricultural waste as a source of ruminant forage. Interviews were conducted by using a questionnaire guide. Questionnaires were used as data characteristics of farmers, how maintenance beef and way of feeding. The selected district is Cilimus, Japara and Cigugur based on the largest ruminant population as a recommendation by local government of Kuningan Regency. Data of agriculture wastes nutrient composition were obtained from laboratory analysis. Samples were obtained from the observation district with 3 repeatations of each commodity retrieval from 3 types of agriculture waste that the most widely used as feed. Secondary data was obtained from Kuningan Regency Veterinary Office, Department of Food Crops and the Central Statistics Agency.

\section{Descriptive Data Analysis}

Descriptive analysis method was used to analysis data consisting of collecting, compiling, and depicting data (Mattjik and Sumertajaya, 2000).

\section{The Potential of Agriculture Wastes as Beef Cattle Feed}

Nutrient composition was analyzed using proximate analysis method. Data of feed quality which evaluated was the content of dry matter $(\mathrm{DM})$, crude protein $(\mathrm{CP})$, crude fiber $(\mathrm{CF})$, eter extract (EE), material extract without nitrogen (NFE) (AOAC, 2005). Total digestible nutrients (TDN) was calculated according to Owens et al. (2010).

The potential of agricultural waste was 
calculated based on dry matter (DM), crude protein $(\mathrm{CP})$, and total digestible nutrients (TDN) production of each commodity. Fresh waste production data was obtained by calculating the fresh weight of plant parts that can be used for feed. Data available in the statistics is in a fresh crop production data that can be used for food, agricultural waste instead of production data. Therefore, needed conversion of parts that can be used for feed.

The proportion of food and feed from each plant was converted into percent (Table 1). The proportion was obtained by taking an integral part of the rice plant without roots (up to a sickle at harvest), sweet potatoes and peanuts of each weighed weight. Each plant species were separated each section used for food and feed and then weighed weight per part. Data whole plant weight and weight per plant part used to calculate the proportion of food and feed. The data for the proportion of food and feed was calculated by the following calculation:

PrFood (\%) $=\frac{\text { weight of the part for food }(\mathrm{kg})}{\text { weight of whole plant yield }(\mathrm{kg})} \times 100 \%$

PrFeed $(\%)=100 \%-\operatorname{PrFood}(100)$

Where:

PrFood : Food proportion

PrFeed : Feed proportion

Data proportion of plants was used to calculate the amount of fresh production of agricultural waste. The calculation of the fresh waste production are as follows:

FWp (ton/year) $)=\left(\right.$ agriculture production (ton/year) $\left.\times \frac{100}{\operatorname{PrF} F o d(\%)}\right) \times \operatorname{PrFeed}(\%)$

Where:

FWp : Fresh agricultural waste production

Production of agricultural waste was calculated by fresh waste production and dry matter (DM) from agricultural waste. The calculation was as follows:

DM production $($ ton $/$ year $)=\mathrm{FWp}($ ton $/$ year $) \times \mathrm{DM}$ content $(\%)$

Production of crude protein (CP) and total digestible nutrients (TDN) from agricultural waste were calculated based on the dry matter. The calculation of the production of crude protein (CP) and total digestible nutrients (TDN) were calculated with the following formula:

CP Productin $\left(\frac{\text { ton }}{\text { year }}\right)=$ Dry Matter production $\left(\frac{\text { ton }}{\text { year }}\right) \times C P$ content $(\%)$

TDN Production $\left(\frac{\text { ton }}{\text { year }}\right)=$ Dry Matter production $\left(\frac{\text { ton }}{\text { year }}\right) \times$ TDN content $(\%)$

\section{Analysis of Increasing Ruminant Population Capacity per District}

\section{Analysis of Location Quation (LQ)}

LQ method Hendayana, 2003) was used to determine district that will be developed. LQ calculation method as follow:

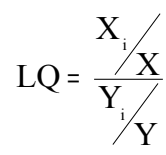

Where:

$\mathrm{X}_{\mathrm{i}}$ : Beef cattle population in a district

$\mathrm{X}$ : Total livestock population in a district

$\mathrm{Y}_{\mathrm{i}}$ : Beef cattle population in Kuningan Regency

$\mathrm{Y}$ : Total livestock population in Kuningan Regency

$\mathrm{LQ} \geq 1$ indicates that the district was a farming area and had a ready human resources for livestock development.

$\mathrm{LQ}<1$ indicates that the district was not a farming area and had no a ready human resources for livestock development.

Capacity of increasing beef cattle population calculation required data of livestock population

Table 1. Agriculture Wastes Proportion Used as Feed ${ }^{\mathrm{a}}$

\begin{tabular}{lllll}
\hline \multirow{2}{*}{ Commodity } & \multirow{2}{*}{ Part for Feed } & & \multirow{2}{*}{ Part for Food } & \multicolumn{2}{c}{ Proportion (\%) } \\
\cline { 4 - 5 } & & & Feed & Food \\
\hline Rice & Leave and stems & Grains & 80.80 & 19.20 \\
Sweet potato & Leave and stems & Tubers & 25.93 & 74.07 \\
Peanut & Leave and stems & Grains+ear grains & 59.24 & 40.76 \\
\hline
\end{tabular}

${ }^{\mathrm{a} B a s e d}$ on fresh matter 
(AU), the total requirement of $\mathrm{DM}, \mathrm{CP}$, and TDN, and untapped production of agriculturel waste. The calculations were performed as follow:

1. Calculation of livestock population was:

$\mathrm{X}_{\mathrm{Rij}} \mathrm{AU}=\mathrm{X}_{\mathrm{Rij}}($ head $) \times \mathrm{S}_{\mathrm{ij}}(\%) \times \mathrm{K}_{\mathrm{ij}}(\mathrm{AU} /$ head $)$

Where:

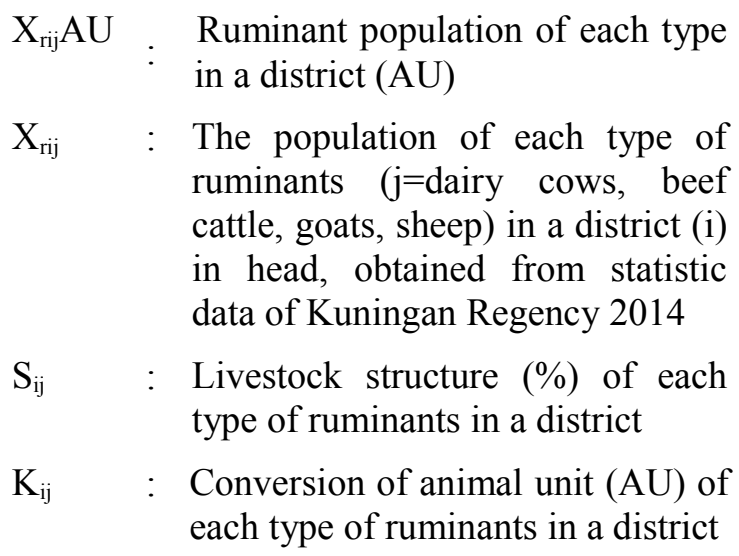

Table 2 presents the illustration of ruminants structure in West Java on the basis of AU. AU conversion for calf was $0.25 \mathrm{AU}$ head $^{-1}$, young cattle was $0.5 \mathrm{AU}^{\text {head }}{ }^{-1}$; bull or cow was $1 \mathrm{AU}$ head $^{-1}$. Kid or lamb was $0.035 \mathrm{AU}^{\text {head }}{ }^{-1}$; young goat or sheep was $0.07 \mathrm{AU}$ head $^{-1}$; buck or doe or ram or ewe was $0.14 \mathrm{AU}_{\text {head }}^{-1}$.

2. The total requirements of dry matter (DM),

\begin{tabular}{|c|c|c|c|c|c|c|}
\hline & \multicolumn{5}{|c|}{ Ration Composition } & \multirow{3}{*}{$\begin{array}{l}\mathrm{F}: \mathrm{C} \\
(\%)\end{array}$} \\
\hline & \multirow{2}{*}{$\mathrm{DM}(\mathrm{kg})$} & \multicolumn{2}{|c|}{$\mathrm{CP}$} & \multicolumn{2}{|c|}{ TDN } & \\
\hline & & $\%$ & $\mathrm{~kg}$ & $\%$ & $\mathrm{~kg}$ & \\
\hline Beef cattle ${ }^{1)}$ & 8.9 & 12.60 & 1.12 & 70.00 & 6.23 & $40: 60$ \\
\hline Dairy cattle ${ }^{2)}$ & 12.4 & 11.90 & 1.48 & 68.00 & 8.43 & $70: 30$ \\
\hline Goat $^{3)}$ & 1.58 & 13.29 & 0.21 & 79.75 & 1.26 & $60: 40$ \\
\hline Sheep ${ }^{3)}$ & 1.41 & 12.27 & 0.17 & 79.43 & 1.12 & $60: 40$ \\
\hline
\end{tabular}
crude protein (CP) and total digestible nutrients (TDN) of ruminant forage referred to the need per head of cattle forage (NRC, 2000; 2001; 2007) is presented in Table 3. Agricultural waste rice straw was used as feed for ruminants limited to a maximum of $2 \%$ of body weight based on the dry matter (Setiyadi et al., 2013). Therefore, the

Table 2. Ruminants Structure in West Java (\%)

\begin{tabular}{lccc}
\hline Ruminants & $\begin{array}{c}\text { Calf/Kid/ } \\
\text { Lamb }\end{array}$ & Young & Mature \\
\hline Beef cattle & 16.08 & 34.72 & 49.20 \\
Dairy cattle & 22.85 & 23.56 & 53.59 \\
Goat & 26.66 & 26.54 & 46.79 \\
\hline Sheep & 28.32 & 26.41 & 45.26 \\
\hline
\end{tabular}

Table 3. Ruminant Requirements (head/day) on Nutrient

Forage Requirement

Ruminants

Rice straw

$\begin{array}{ccc}\mathrm{DM}(\mathrm{kg}) & \mathrm{CP} & \mathrm{TDN} \\ \mathrm{kg} & \mathrm{kg}\end{array}$

$\begin{array}{lll}\text { Beef cattle }^{1)} & 2.92 & 0.14 \\ \text { Dairy cattle }^{2)} & 5.60 & 0.27 \\ \text { Goat }^{3)} & 0.30 & 0.01 \\ \text { Sheep }^{3)} & 0.48 & 0.02\end{array}$

1.43

2.75

0.15

0.24
Others

$\begin{array}{ccc}\mathrm{DM}(\mathrm{kg}) & \mathrm{CP} & \mathrm{TDN} \\ & \mathrm{kg} & \mathrm{kg} \\ 0.64 & 0.44 & 0.73 \\ 3.08 & 0.83 & 2.84 \\ 0.65 & 0.14 & 0.63 \\ 0.37 & 0.10 & 0.45\end{array}$

Data was based on calculation of appropriate with $\left.{ }^{1}\right) \mathrm{NRC}(2000) ;{ }^{2)} \mathrm{NRC}(2001) ;{ }^{3)} \mathrm{NRC}(2006)$; F: Forage, C: Concentrate 
calculation of the value of rice straw needs separated from the value of agricultural waste needs other than rice straw. Total nutrient requirements of ruminant forage annually selected by district calculated by the following calculation:

$$
\mathrm{K}_{\text {HRi(a,b,c) }}=\sum_{\mathrm{j}=1}^{4} \frac{\mathrm{X}_{\mathrm{Rij}} \mathrm{XK}_{\text {HRij(a,b,c) }} \times 365}{1,000}
$$

Where:

$$
\begin{aligned}
& \mathrm{K}_{\mathrm{HRi}} \text { Total nutrient needs } \\
& \text { : }(\mathrm{DM} / \mathrm{CP} / \mathrm{TDN}) \text { of all ruminant } \\
& \text { forage in a district (tons/year) } \\
& \mathrm{X}_{\mathrm{Rij}} \mathrm{AU} \text { : Ruminant population of each type } \\
& \text { in a district (AU) } \\
& \mathrm{K}_{\mathrm{HRij}} \text { : Nutrient needs (DM/CP/TDN) of } \\
& \text { a : DM (ton/year) } \\
& \text { b : CP (ton/year) } \\
& \text { c : TDN (ton/year) }
\end{aligned}
$$

3. The production value of agricultural waste and total forage nutrient needs, used to calculate the residual agricultural waste that has not been used as feed. Untapped agricultural waste will be used to increase the number of beef cattle in Kuningan Regency, West Java. Untapped agricultural waste in Indonesia amounted to $70 \%$ of the total production of agricultural wastes (Indraningsih et al., 2011). Residual agricultural waste selected by district was calculated with the following formula:

Residual Agricultural Waste $(a, b, c)=$

(Prod.LP ${ }_{1(a, b, c)}$ ton/year x 70\%) - $\left(\mathrm{K}_{\mathrm{HR} l(a, b, c)}\right.$ ton/year) Where:

$$
\begin{array}{ll}
\text { Prod. }_{\mathrm{LP}} \mathrm{:} & \begin{array}{l}
\text { Production of agricultural waste } \\
\text { (tons/year) in a district }
\end{array} \\
\mathrm{K}_{\mathrm{HRi}} & \begin{array}{l}
: \text { Total nutrient needs (DM/CP/TDN) } \\
\text { of all ruminant forage in a district } \\
\text { (tons/year) }
\end{array} \\
\mathrm{a} & : \mathrm{DM} \text { (ton/year) } \\
\mathrm{b} & : \mathrm{CP} \text { (ton/year) } \\
\mathrm{c} & : \text { TDN (ton/year) }
\end{array}
$$

4. Capacity additions of beef cattle population was calculated based on the production of $\mathrm{DM} / \mathrm{CP} / \mathrm{TDN}$ of agricultural waste. The calculation in each district selected in Kuningan Regency was as follow:

KPPTR $_{\text {Spi }(a, b, c)(A U)}=\frac{\text { Residual Agricultural Waste }(a, b, c)(\text { ton } / \text { year })}{K_{\text {HSpi }(a, b, c)}\left({ }^{\text {ton } / \text { year }}\right)}$

Where:

KPPTRspi : Capacity addition of beef cattle population in a district (AU)

KHspi : Beef cattle forage nutrient needs in a district (tons/year)

$$
\begin{array}{ll}
\text { a } & : \text { DM (ton/year) } \\
\text { b } & : \text { CP (ton/year) } \\
\text { c } & : \text { TDN (ton/year) }
\end{array}
$$

Capacity addition of beef cattle population in Kuningan Regency was the total value of all capacity addition of beef cattle population in the districts selected. The value of capacity addition of beef cattle population in Kuningan Regency was total of beef cattle that can be added in Kuningan Regency using agricultural waste forage source. The calculation of capacity additions of beef cattle population in Kuningan Regency was as follow:

$$
\mathrm{KPPTR}_{\mathrm{Sp}}(\mathrm{AU})=\sum_{\mathrm{i}=1}^{9} \mathrm{KPPTR}_{\mathrm{Spi}}(\mathrm{AU})
$$

Where:

KPPTRsp Capacity addition of beef cattle : population in Kuningan Regency (AU)

\section{RESULTS AND DISCUSSION}

\section{The Potential of Agriculture Waste in Kuningan Regency}

Kuningan Regency has 32 districts but there are nine districts which are an farming-based area and have the human resources who can undertake beef cattle development ( $L Q \geq 1)$. Table 4 shows the production estimation of agriculture waste in the suitable districts considered for beef cattle development. On the basis of analysis, the highest production waste used is rice straw, and the lowest is peanut hay. High potential of rice straw was farmers in Southeast Asia, including Indonesia, produce approximately $80 \%$ rice in the world (Sarnklong et al., 2010). Dry matter production of agriculture wastes showed the highest value and crude protein content has the lowest value. Donkin et al. (2013) explained that the chemical composition of feed determined feed 
quality. In fattening business, cattle that received rations in the form of agriculture waste is an average shortage of crude CP around $18.49 \%$ and TDN around $18.47 \%$ from the standard requirement (Syukur and Afandi, 2009). Agriculture waste in Kuningan Regency is a source of fiber based on the nutrient content. Energy requirement of ruminant is $70-80 \%$ derived from fiber. Table 5 presents the composition of the nutrient content of agriculture wastes in Kuningan Regency. Rice straw was used as feed for ruminant is limited about $2 \%$ of body weight based on dry matter because hard fermentable carbohydrate and lignin and silica in straw which poorly digested by ruminant (Setiyadi et al., 2013).

\section{Farmer Characteristics in Kuningan Regency}

The results of survey indicate that the age of farmers in Kuningan Regency is productive age as much as $83.87 \%$ (Table 6). Farmers who have the productive age considered to have dynamic mindset and a strong physically ability to manage livestock bussiness (Umam et al., 2012). The

Table 4. Estimated Production of Agriculture Wastes in District that Suitable for Beef Cattle Development in Kuningan Regency

\begin{tabular}{|c|c|c|c|c|c|c|c|c|}
\hline \multirow[b]{2}{*}{ District } & \multicolumn{4}{|c|}{ Rice Straw Production } & \multicolumn{4}{|c|}{ Others Production } \\
\hline & $\begin{array}{l}\text { Fresh } \\
\text { matter } \\
\text { (ton/yr) }\end{array}$ & $\begin{array}{c}\mathrm{DM} \\
\text { (ton/yr) }\end{array}$ & $\begin{array}{c}\mathrm{CP} \\
\text { (ton/yr) }\end{array}$ & $\begin{array}{c}\text { TDN(ton/ } \\
\mathrm{yr})\end{array}$ & $\begin{array}{l}\text { Fresh } \\
\text { matter } \\
\text { (ton/yr) }\end{array}$ & $\begin{array}{c}\mathrm{DM} \\
\text { (ton/yr) }\end{array}$ & $\begin{array}{c}\mathrm{CP} \\
\text { (ton/yr) }\end{array}$ & $\begin{array}{c}\text { TDN } \\
\text { (ton/yr) }\end{array}$ \\
\hline Luragung & $53,888.31$ & $19,270.46$ & 946. & 9,45 & 212.07 & 60.18 & 7.85 & 35.46 \\
\hline Cibingbin & $49,357.62$ & $17,650.29$ & 866.63 & $8,657.46$ & 164.81 & 51.19 & 6.53 & 31.03 \\
\hline Subang & $41,377.36$ & $14,796.54$ & 726.51 & $7,257.70$ & 163.50 & 49.86 & 6.39 & 30.05 \\
\hline Ciwaru & $38,914.64$ & $13,915.88$ & 683.27 & $6,825.74$ & 51.89 & 16.12 & 2.05 & 9.77 \\
\hline Maleber & $36,259.43$ & $12,966.37$ & 636.65 & $6,360.00$ & 310.06 & 86.86 & 11.37 & 50.95 \\
\hline Cilebak & $32,433.81$ & $11,598.33$ & 569.48 & $5,688.98$ & 201.44 & 62.57 & 7.98 & 37.92 \\
\hline Cibeureum & $30,760.58$ & $10,999.98$ & 540.10 & $5,395.49$ & 211.61 & 65.73 & 8.38 & 39.84 \\
\hline Cimahi & $28,512.90$ & $10,196.21$ & 500.63 & $5,001.24$ & 152.65 & 45.97 & 5.91 & 27.60 \\
\hline Karangkancana & $23,030.71$ & $8,235.78$ & 404.38 & $4,039.65$ & 51.89 & 16.12 & 2.05 & 9.77 \\
\hline Total & $334,535.36$ & $119,629.84$ & $5,873.83$ & $58,678.44$ & $1,519.92$ & 454.59 & 58.51 & 272.39 \\
\hline
\end{tabular}

Calculated from statistic of Kuningan Regency (2013)

Table 5. Nutrient Composition of Agriculture Wastes in Kuningan Regency

\begin{tabular}{lrrrrrrr}
\hline \multirow{2}{*}{ Materials } & \multicolumn{7}{c}{ Nutrient Composition (\%) } \\
\cline { 2 - 8 } & DM & Ash & CF & EE & CP & NFE & TDN \\
\hline Rice straw & 53.63 & 17.54 & 29.98 & 1.88 & 4.91 & 45.68 & 49.05 \\
Sweet potato straw & 19.28 & 11.05 & 37.04 & 1.64 & 14.68 & 35.59 & 49.64 \\
Peanut hay & 71.71 & 8.72 & 26.78 & 2.25 & 12.75 & 49.50 & 60.61 \\
\hline
\end{tabular}

Ash, CP, EE, CF, NFE, TDN in 100\% DM. DM (dry matter); CP (crude protein); EE (ether extract); CF (crude fiber); NFE (non fiber extract); TDN (total digestible nutrient). 
Table 6. Beef Cattle Farmers Characteristics in Kuningan Regency ${ }^{a}$

\begin{tabular}{lr}
\hline \multicolumn{1}{c}{ Farmer Description } & $\%$ \\
\hline Age & \\
$20-50$ & 83.87 \\
$51-80$ & 16.13 \\
Education & \\
$\quad$ Elementary School & 61.29 \\
Junior High School & 22.58 \\
Senior High School & 12.90 \\
$\quad$ University & 3.23 \\
Occupation & \\
$\quad$ Main Job & 9.68 \\
Side Job & 90.32 \\
Farming Experience (year) & \\
0 - 5 & 9.68 \\
$\quad 6-10$ & 90.32 \\
\hline
\end{tabular}

$61.29 \%$ farmers in the Kuningan Regency were elementary school graduate. The level of education affects a livestock farming quality. Technology induction and education development of beef cattle programs as a way of feeding and ways of raising beef cattle will be difficult to implement when farmer has less knowledge (Murwanto, 2008). Farming activities were undertaken as the second job because most of the livestock-farmers in Kuningan Regency were farmers and traders. There was a variation of farming experience in livestock but almost more than 5 years. Many experiences of livestock production improve skill level and knowledge of farmers to apply the technology then everything will be easier and faster (Wibowo and Haryadi, 2006; Baba 2011).

\section{Population Increased Capacity of Beef Cattle in Kuningan Regency}

Production of agriculture waste per year based on DM, CP, and TDN can be used to estimate the addition of beef cattle number in Kuningan Regency. Capacity of increasing ruminant population $\left(\mathrm{KPPTR}_{\mathrm{SP}}\right)$ for the highest

Table 7. Capasity Addition of Beef Cattle Population (KPPTR) in Kuningan Regency based on Agriculture Waste

\begin{tabular}{|c|c|c|c|c|c|c|c|c|c|}
\hline \multirow[b]{2}{*}{ District } & \multirow[b]{2}{*}{ LQ } & \multicolumn{4}{|c|}{ Rice Straw } & \multicolumn{3}{|c|}{ Others } & \multirow[b]{2}{*}{$\begin{array}{c}\text { KPPTR }_{\text {SP }} \text { of } \\
\text { beef cattle } \\
\text { (AU) }\end{array}$} \\
\hline & & $\begin{array}{c}\text { TDN } \\
\text { production } \\
\text { (ton/year) }\end{array}$ & $\begin{array}{l}\text { TDN } \\
\text { require- } \\
\text { ment } \\
\text { (ton/year) }\end{array}$ & $\begin{array}{c}\text { TDN } \\
\text { excess } \\
\text { (ton/year) }\end{array}$ & $\begin{array}{c}\text { KPPTR }_{\mathrm{SP}} \text { of } \\
\text { beef cattle } \\
(\mathrm{AU})\end{array}$ & $\begin{array}{c}\mathrm{TDN} \\
\text { production } \\
\text { (ton/year) }\end{array}$ & $\begin{array}{c}\text { TDN } \\
\text { require- } \\
\text { ment } \\
\text { (ton/year) }\end{array}$ & $\begin{array}{c}\text { TDN } \\
\text { excess } \\
\text { (ton/year) }\end{array}$ & \\
\hline ragung & 1.58 & $9,452.16$ & 573.48 & $8,878.68$ & 17 & 35.46 & 404.16 & -368.71 & $-1,383.77$ \\
\hline Cibingbin & 1.51 & $8,657.46$ & $1,397.29$ & $7,260.18$ & $13,909.71$ & 31.03 & 1034.84 & $-1,003.82$ & $-3,767.38$ \\
\hline Ciwaru & 1.57 & $6,825.74$ & 543.44 & $6,282.29$ & $12,036.20$ & 9.77 & 377.89 & -368.12 & $-1,381.58$ \\
\hline ho & 1.1 & $7,257.70$ & 1,292 & $5,965.39$ & 11,42 & 3 & 60 & -668.36 & -2 , \\
\hline Maleber & 1.59 & $6,360.00$ & $1,414.98$ & $4,945.03$ & $9,474.14$ & 50.95 & 1056.61 & $-1,005.66$ & $-3,774.29$ \\
\hline 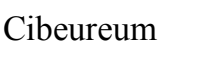 & 1.51 & 395.49 & 586 & $4,809.36$ & 9,21 & 39.8 & 571 & -531.72 & $-1,995.58$ \\
\hline Cilebak & 1.54 & $5,688.98$ & $1,630.87$ & $4,058.11$ & $7,774.89$ & 37.92 & 1188.91 & $-1,150.99$ & $-4,319.73$ \\
\hline Karangkancana & 1.62 & $4,039.65$ & 556.45 & $3,483.20$ & $6,673.44$ & 9.77 & 366.08 & -356.32 & $-1,337.27$ \\
\hline Cimahi & 1.76 & $5,001.24$ & $1,766.87$ & $3,234.37$ & $6,196.70$ & 27.60 & 1223.81 & $-1,196.21$ & $-4,489.43$ \\
\hline Total & & 678.44 & $9,761.84$ & $48,916.60$ & $93,718.94$ & 272.39 & 6922.29 & $-6,649.90$ & $-24,957.42$ \\
\hline
\end{tabular}

LQ: Location Quation; TDN: total digestyble nutrient; Data was calculated from statistic of Kuningan Regency 2013 
value of beef cattle using rice straw generally is based on CP and the lowest value is based on TDN. KPPTR $R_{S P}$ value of beef cattle use an effective KPPTR $_{S P}$ value. Its illustrate the total potential of agriculture waste which can meet an actual requirement of the lowest value for beef cattle. The effective $\mathrm{KPPTR}_{\mathrm{SP}}$ from data obtained is KPPTR by TDN supply from rice straw. The estimated effective KPPTR in the selected districts for beef cattle development is presented in Table 7.

District that can improve the highest number of beef cattle population was Luragung as much as 17,010 AU per year and the lowest number was Cimahi as much as 2,776 AU on 2013. It achieved $44.8 \%$ from beef cattle number that could be added. All districts having potential development of beef cattle showed value of effective KPPTR $_{S P}$ of beef cattle as much as 93,718 AU per year. Total beef cattle population in Kuningan Regency on 2013 was 22957 AU which achieved $24.5 \%$ from the total beef cattle number that could be added.

\section{CONCLUSION}

Beef cattle farmers in Kuningan Regency using traditionally system. Kuningan Regency has a potency of local feed origin agriculture waste such as rice straw, sweet potato straw and peanut straw. The highest production is rice straw. Nutrient quality of agriculture wastes is a fiber source for ruminant ( $>18 \%$ of DM). District that having the highest potential for beef cattle development in the Kuningan Regency is Luragung.

\section{REFERENCES}

AOAC (Association of Official Analytical Chemists). 2005. Official Methods of Analysis. Washington DC : Association of Official Analytical Chemists.

Baba, S., Isbandi, Mardikanto and T. Waridin. 2011. Faktor-faktor yang mempengaruhi tingkat partisipasi peternak sapi perah dalam penyuluhan di Kabupaten Enrekang. Jurnal Ilmu dan Teknologi Peternakan. 1(3):193208.

BPS (Badan Pusat Statistik Kabupaten Kuningan). 2014. Kabupaten Kuningan dalam Angka 2013.

Donkin, S. S., P. H. Doane, and M. J. Cecava. 2013. Expanding the role of crop residues and biofuel co-products as ruminant feedstuffs. Anim. Frontiers. 3(2):54-60.

Hendayana, R. 2003. Aplikasi metode location quatient (LQ) dalam penentuan komoditas unggulan nasional. Informatika Pertanian. 12:658-675

Imran, S.P.S Budhi, N. Ngadiyono, and Dahlanuddin. 2012. Pertumbuhan pedet sapi pali lepas sapih yang diberi rumput lapangan dan disuplementasi daun turi (Sesbania grandiflora). J. Ilmu Ternak dan Tanaman. 2(2):55-60

Indraningsih, R. Widiastuti, and Y. Sani. 2011. Limbah pertanian dan perkebunan sebagai pakan ternak: Kendala dan Prospeknya. Lokakarya Nasional Ketersediaan IPTEK dalam Pengendalian Penyakit Strategis pada Ternak Ruminansia Besar. 4(3):99-115.

Mattjik, A. A. and M. Sumertajaya. 2000. Perancangan Percobaan. Jilid I. Bogor: IPB Press. P.7-17.

Murwanto, A.G. 2008. Karakteristik peternak dan tingkat masukan teknologi peternakan sapi pedaging di Lembah Prafi Kabupaten Manokwari. J. Ilmu Peternakan. 3(1):8-15.

NRC (National Reseach Council) (US). 2000. Nutrient Requirement of Beef Cattle. $6^{\text {th }}$ rev.ed. Washington DC: National Academy Press.

NRC (National Reseach Council) (US). 2001. Nutrient Requirement of Dairy Cattle. $7^{\text {th }}$ rev.ed. Washington DC: National Academy of Science.

NRC (National Reseach Council) (US). 2007. Nutrient Requirement of Small Ruminant. 6th rev.ed. Washington DC: National Academy of Science.

Owens, F.N., D.A. Sapienza and A.T. Hassen. 2010. Effect of nutrient composition of feeds on digestibility of organic matter by cattle: a review. J. Anim Sci. 88: 151-169.

Sarnklong, C., J. W. Cone, W. Pellikaan and W. H. Hendriks. 2010. Utilization of rice straw and different treatments to improve its feed value for ruminants: A Review. Asian-Aust J Anim Sci. 23(5):680-692.

Setiyadi, S., R. Sri and B. Muhammad. 2013. Digestibility neutral detergent fiber (NDF), acid detergen fiber (ADF) and crude fiber buffaloes feed based of rice straw. J. Ilmiah Peternakan. 1(2):546-553.

Sugiyono. 2011. Statistika untuk Penelitian. Bandung: Alfabeta.

Suprapto, H., F.M. Suhartati and T. Widiyastuti. 
2013. Digestibility of crude fiber and crude fat complete feed jute waste with different protein sources on post weaning Etawa cross breed goat. J. Ilmiah Peternakan. 1(3):938-946.

Syukur, S.H. and Afandi. 2009. Perbedaan waktu pemberian pakan pada sapi jantan lokal terhadap income over feed cost. J. Agroland. 16(1):72-77

Umam, K., N. Kusrini, and D. Kurniati. 2012. Hubungan antara karakteristik dengan persepsi peternak terhadap inseminasi buatan pada sapi potong Kelurahan Tuantuan Kecamatan Benua Kayong Kabupaten Ketapang. J. Sosial Ekonomi Pertanian. $1(3): 23-28$.

Wibowo, S.A. and F.T. Haryadi. 2006. Faktor karakteristik peternak yang mempengaruhi sikap terhadap program kredit sapi potong di kelompok peternak Andiniharjo Kabupaten Sleman Yogyakarta. Media Peternakan. 29(3) :176-186. 